\title{
PERAN MANAJEMEN KEUANGAN SEKOLAH DI DALAM PENDIDIKAN
}

\author{
Rabi Yati \\ Email: 2010128120009@mhs.ulm.ac.id \\ Program Studi Pendidikan IPS Fakultas Keguruan dan Ilmu Pendidikan \\ Universitas Lambung Mangkurat \\ Banjarmasin
}

\begin{abstract}
Abstrak
Dalam seluruh aktivitas sekolah tidak terlepas dari yang namanya pendanaan atau keuangan karena seluruh kegiatan sekolah dan keberlangsungan sekolah semuanya terikat kepada keuangan. Oleh karena itu, diperlukan manajemen keuangan sekolah yang baik untuk mencapai tujuan tersebut, dimana beberapa aktivitas manajemen keuangan meliputi dari perencanaan, pembukuan, pembelanjaan, pengawasan dan pertanggungjawaban keuangan sekolah, dengan tujuan untuk meningkatkan keefektifitasan serta efisiensi dalam penggunaan dan pemanfaatan keuangan sekolah. Pada dasarnya semua pihak yang memiliki hubungan dalam sekolah juga memiliki peran di dalam administrasi keuangan sekolah, dimana bukan hanya kepala sekolah yang bertanggungjawab, teapi seluruh aparatur sekolah sepertihalnya guru dan lain-lain. Hal ini menuunjukkan bahwa manajemen dan administrasi sangatlah penting di dalam mengatur keuangan sekolah. Ditulisnya artikel ini diharapkan dapat meningkatkan pengetahuan serta literasi mengenai pentingnya peran manajemen administrasi sekolah terutama dalam hal keuangan sekolah untuk mencapai tujuan pendidikan.
\end{abstract}

Kata kunci: Manajemen, Keuangan, Sekolah, pendidikan

\section{PENDAHULUAN}

Pendidikan merupakan hal yang sangat dibutuhkan oleh manusia untuk meningkatkan taraf hidup dan mutu manusia. Pendidikan memiliki peranya tersendiri yaitu guna mencapai tujuan dan cita-cita bangsa yaitu mencerdaskan kehidupan bangsa. Untuk mencapai tujuan dan cita-cita bangsa inilah, oleh karena itu di dalam sistem dan pelaksanaan pendidikan formal dipelukan opengaturan yang sempurna sehingga tujuan tersebut dapat tercapai secara efektif dan efesien. (Akma. 2021)

Manajemen administrasi sekolah merupakan salah satu perangkat atau sistem pengorganisasian yang terdapat di dalam sekolah yang memiliki peran dalam pengorganisasian, pengarahan, penyusunan, perencanaan, serta pengawasan sumber daya manusia serta berbagai aspek yang diperlukan di dalam pendidikan guna mencapai tujuan 
tertentu dengan prinsip efesiensi dan efektifitas. Manajemen administrasi sekolah ini mengatur dan merencanakan beberapa aspek yang berhubungan dengan pelaksanaan pendidikan diantaranya administrasi organisasi, kurikulum, kepegawaian, peserta didik, sarana dan prasarana, tata usaha, tata hubungan masyarakat serta keuangan atau pembiyayaan.

Di dalam pendidikan seluruhnya harus melalui pengorganisasian dan perencanaan yang baik sepertihalnya di dalam kurikulum yang melakukan berapa kali perubahan untuk mencapai tujuan dari pendidikan yang diinginkan (Abbas, E.W. 2013). Selain kurikulum di dalam pendidikan juga tersapat komponen lain yang diperlukan untuk pelaksanaan pendidikan, seluruhnya diatur, diorganisasikan dan di rencanakan dengan baik untuk tercapainya tujuan dari pendidikan. Oleh karena itu manajemen administrasi sekolah sangat dipelukan di dalam menangani beberapa komponen-komponen yang berhubungan dengan aktivitas pendidikan dalam lingkup sekolah, untuk menggapai pendidikan yang bersifat efektif dan efisien.

Salah satu bentuk operasional pendidikan yang sangat diperlukannya manajemen baik dalam bentuk perencanaan, pengelolaan, maupun pemanfaatan kebutuhan sekolah adalah keuangan sekolah, dimana keungan merupakan aspek yang sangat penting di dalam berjalannya proses pendidikan untuk keberlangsungan sekolah, karena di dalam pendidikan terdapat berbagai macam kebutuhan, pemasukan dan pengeluaran dana yang harus tepat pengelolaannya untuk mencapai tujuan yang tepat sasaran. Di dalam manajemen keuangan sekolah, pihak sekolah harus paham betul mengenai bagaimana pengalokasian dana, sumber dana yang masuk dan sebagainya karena apabila dana yang dimiliki sekolah tidak memiliki pengelolaan serta manajeman yang baik, sekolah akan berpotensi mengalami kemunduran karena tidak terpenuhinya berbagai aspek yang memerlukan pengalokasian dana baik itu dari segi fasilitas sekolah, gajih pegawai aset dan lain hal sebagainya yang memerlukan perencanaan dana yang tepat demi tercapainya tujuan pendidikan.

Oleh karena itu, ditulisnya artikel ini bertujuan untuk mengetahui bagaimana sistem dan cara manajemen administrasi keuangan sekolah bekerja serta bagaimana cara dan pengelolaan keuangan sekolah yang baik dan benar serta menambah wawasan dan ilmu pengetahuan mengenai manajemen administrasi sekolah pada bidang keuaangan 
agar seorang pendidik pun tau bagaimana mekaisme di dalam sekolah itu berjaln dan dapat bekerja secara efektif dan efesien sesuai dengan tujuan yang ingin dicapai di dalam pendidikan.

\section{METODE}

Metode yang digunakan dalam penulisan artikel ini adalah menggunakan metode desktiptif kuantitatif yang mendefinisikan dan menggambarkan bagaimana manajemen administrasi di dalam perencanan serta pengawasan keuangan sekolah serta beberapa peran guru administrasi keuangan sekolah sebagai salah seorang yang banyak terlibat dalam kegiatan pendidikan di sekolah. Untuk pengumpulan data-data yang terdapat di dalam artikel ini adalah menggunakan studi kepustakaan atau studi literatur yang diambil dari buku, jurnal-jurnal atau artikel-artikel penelitian terdahulu sehingga terjami keakribilitasannya. Dan dari data-data yang telah dikumpulkan tersebut, kemmudian datadata tersebut di rekonstruksi ulang sehingga mendapatkan hasil dan dapat ditari kesimpulan dari rumusan masalah dan yang ditujukan.

\section{HASIL DAN PEMBAHASAN}

Manajemen administrasi keuangan sekolah merupakan suatu manajemen perencanaan dan pengelolaan di dalam sekolah yang memili fungsi untuk mengelola seluruh aktifitas keuangan di dalam suatu sekolah untuk mencapai tujuan sekolah yaitu menciptakan pengelolaan dan hasil yang efektif dan efisien. Keuangan sekolah memiliki fungsi yang sangat vital dan strategis, karena keuangan sekolah mencakup seluruh aktivitas sekolah sepertihalnya pendanaan, fasilitas, renovasi, sarana dan prasarana maupun aktivitas di dalam sekolah lainnya sangat bergantung terhadap keuangan sekolah. Oleh karena itu di dalam pengelolaannya diperlukan sistem manajemen dan administrasi keuangan yang baik guna mencapai tujuan yang efektif dan efisien serta seluruh aktivitas di dalam sekolahpun berjalan dengan lancar dan dapat meminnimalisir berbagai kendala yang dihadapi oleh sekolah dalam bentuk pendanaan atau keuangan. (Akma. 2021)

Manajemen keuangan sekolah adalah cara suatu instansi (sekolah) dalam mengadakan pengelolaan maupun pertanggung jawaban seluruh atau segala jenis bentuk aktivitas keuangan sekolah baik dalam hal penggunaan, pengeluaran, keuangan yang 
diterima dari siswa maupun yang didapat dari berbagai sumber dana lainnya. Manajemen keuangan di sekolah dinilai sebagai suatu hal yang sangat penting bagi kelangsungan sekolah, hal ini dikarenakan keuangan adalah semua dari segala sumber berlangsungnya suatu aktivitas operasional sekolah oleh karena itu manajemen atau pengaturan keuangan yang baik sangat diperlukan dalam menjalankan segara aktivitas dan operasional demi keberlangsungan suatu sekolah. (Awaludin, R.F. 2021)

Adapun aktivitas-aktivitas dalam proses manajemen keuangan sekolah antara lain perencanaan, pengawasan, pembukuan, pembelanjaan, pengawasan dan pertanggungjawaban keuangan. Dalam Depdiknas (2000) dijelaskan bahwasanya aktivitas manajemen keuangan adalah pengurusan atau ketatausahaan keuangan yang meliputi berbagai hal seperti halnya pencatatan, perencanaan, pelaksanaan, pertanggungjawaban dan pelaporan. Dengan demikian, manajemen keuangan sekolah juga dapat diartikan sebagai rangkaian aktivitas mengatur keuangan sekolah mulai dari perencanaan, pembukuan, pembelanjaan, pengawasan dan pertanggungjawaban keuangan sekolah. Pembiayaan pendidikan hendaknya dilakukan secara efisien, dimana apabila dikelola dengan benar maka keuangan yang akan dikeluarkan akan menjadi sedikit (efesien), namun dengan sedikitnya dana yang dikeluarkan tetap harus maksimal dan tepat sasaran (efektif). (Putri, A.A. 2020)

Untuk lebih spesifiknya, tujuan dari adanya pengelolaan keuangan sekolah dalam bentuk manajemen administrasi sekolah antara lain:

- Meningkatkan keefektifitasan serta efisiensi dalam penggunaan dan pemanfaatan keuangan sekolah.

- Meningkatkan akuntabilitas maupun transparansi dari keuangan sekolah.

- Meminimalisir adanya penyalahgunaan anggaran sekolah oleh pihak-pihak yang tidak bertanggung jawab.

Pengelolaan atau manajemen pada keuangan sekolah pada dasarnya memiliki beberapa prinsip-prinsip yang tertuang dalam Peraturan Pemerintah Republik Indonesia No.48 Tahun 2008 mengenai Pendanaan Pendidikan prinsip-prinsip tersebut meliputi prinsip transparansi, efisiensi, keadilan, dan akuntabilitas publik. (Hidayat, R. 2017). 
Dalam prinsi transparansi dapat diartikan bahwa di dalam pengelolaan keuangan sekolah tentunya harus memiliki keterbukaan yang sangat jelas. Dimana segala pengeluaran maupun pemasukan dana dalam keuangan sekolah harus ada rinciannya sifatnya harus jelas dan mencakup semua aktivitass keuangan baik pemasukan maupun pengeluaran (Rahmah. N., 2016). Dalam Prinsip efisiensi manajemen keuangan dalam menggunakan sumber daya keuangan harus bisa menyesuaikan antara jumlah dana yang dikeluarkan sekolan dengan apa yang dihasilkan dari penggunaan dana tersebu. Sedangkan untuk Prinsip Akuntabilitas pada manajemen keuangan sekolah dapat diartikan bahwa segala penggunaan atau pemanfaatan keuangan sekolah harus ada pertanggungjawabannya baik itu secara administratif manupun secara normatif. (Eka Fitri. 2020)

Dalam lingkup pertanggung jawaban keuangan sekolah yang paling penting adalah dari menajer sekolah terhadap pemerintah, dan juga terhadap komite sekolah, masyarakat, serta guru-guru adalah laporan mengenai kondisi keungan sekolah (Rebore \& Rebore dalam Narhizrah,2013:185). Penerimaan dan pengeluaran keuangan sekolah harus dilaporkan dan dipertanggungjawabkan secara rutin oleh manajer sekolah sesuai dengan peraturan yang berlaku. Pelaporan dan pertanggungjawaban anggaran yang berasal dari orang tua peserta didik dan masyarakat dilakukan secara rinci dan transparan sesuai dengan sumber dana.

Sedangkan untuk proses administrasi keuangan sekolah dapat berupa beberapa bentuk yang harus di ikuti dengan beberapa perencanaan yaitu penyusunan Recana Pengembangan Sekolah (RPS) yang merupakan perencanaab kegiatan sekolah yang akan datang dan panduan untuk menyelenggarakan pendidikan disekolah baik jangka panjang, menengah maupun pendek yang menjadi penentu masa depan sekolah yang tepat sasaran, sertra konsistensi antara perencanan yang bersatu dalam proses pendanaan. Pada dasarnya seluruh kegiatan sekolah itu harus optimal baik dalam hal pendanaan maupun kontrol, dengan adanya penyusunan RPS ini, diharapkan seluruh kegiatan sekolah itu sesuai dengan yang telah diancang ancang di dalam RPS untuk mencapai suatu keoptimalan dalam hal pengelolaan dana sekolah agar dapat mencapai efesiensi dan keefektifan dalam mencapai kesejahteraan sekolah. (Putri. A.A. 2020) 
Pada dasarnya, di dalam pertanggungjawaban keuangan sekolah seluruh aparatur sekolah atau semua pihak yang terlibat dalam sekolah juga memiliki peran di dalamnya, seluruhnya memiliki tanggung jawan untuk membawa sekolah untuk mencapai tujuan pendidikan yang lebih baik baik kedepannya. Hal ini artinya seluruh tanggung jawab keuangan sekolah tidak hanya bertumpu kepada kepala sekolah saja, melainkan seluruh orang yang terlibat di dalam jalannya kegiatan pendidikan di sekolah memiliki tangung jawab seperti halnya guru, karyawan dan lain hal sebagainya. (Rusmawati, 2013)

Menurut Fitri. E (2020) peran guru dan aparatur lainnya dalam administrasi keuangan sekolah meliputi hal-hal sebagai berikut:

- Membuat perincian dana keuangan pembangunan dalam bentuk file.

- Membuat laporan data usulan pembayaran gaji, rapel kepada Pemerintah Kota.

- Membuat dan merinci aktivitas keuangan baik pemasukan maupun pengeluaran.

- Membuat laporan dana pembangunan pada akhir tahun anggaran.

- Membuat laporan RAPBS (Rancangan Anggaran Pendapatan Bantuan Sekolah).

- Membuat laporan tribulan dana BOS (Bantuan Operasional Sekolah).

- Menyetorkan pajak PPH dan PPN.

- Membagikan rapel atau gaji.

- Membuat dan menyimpan arsip peraturan keuangan sekolah.

\section{SIMPULAN}

Keuangan sekolah memiliki fungsi yang sangat vital dan strategis, karena keuangan sekolah mencakup seluruh aktivitas sekolah sepertihalnya pendanaan, fasilitas, renovasi, sarana dan prasarana maupun aktivitas di dalam sekolah lainnya sangat bergantung terhadap keuangan sekolah. Manajemen keuangan sekolah adalah cara suatu instansi (sekolah) dalam mengadakan pengelolaan maupun pertanggung jawaban seluruh atau segala jenis bentuk aktivitas keuangan sekolah baik dalam hal penggunaan, pengeluaran, keuangan yang diterima dari siswa maupun yang didapat dari berbagai sumber dana lainnya.

Tujuan dari adanya pengelolaan keuangan sekolah dalam bentuk manajemen administrasi sekolah adalah meningkatkan keefektifitasan serta efisiensi dalam 
penggunaan dan pemanfaatan keuangan sekolah. Dengan rangkaian aktivitas mengatur keuangan sekolah mulai dari perencanaan, pembukuan, pembelanjaan, pengawasan dan pertanggung-jawaban keuangan sekolah. Seluruh tanggung jawab keuangan sekolah tidak hanya bertumpu kepada kepala sekolah saja, melainkan seluruh orang yang terlibat di dalam jalannya kegiatan pendidikan di sekolah memiliki tangung jawab seperti halnya guru, dan lainnya yang berhubungan dengan sekolah.

\section{REFERENSI}

Abbas, E. W. (2013). Mewacanakan Pendidikan IPS. Mewacanakan Pendidikan IPS.

Afriansyah, H. (2019). Administrasi Keuangan.

Afriansyah, H. (2019). Pentingnya Administrasi Keuangan dalam Sekolah.

Andiawati, E. (2017, April). Pengelolaan Keuangan Lembaga Pendidikan/Sekolah. In Prosiding Seminar Pendidikan Ekonomi Dan Bisnis (Vol. 3, No. 1).

Awaludin, R. F., Bahri, S., \& Muslih, M. Penerapan Zachman Framework Dalam Perancangan Sistem Informasi Manajemen Keuangan Sekolah. CESS (Journal of Computer Engineering, System and Science), 6(1), 78-83.

Burhanuddin. (1994). Analisis Manajemen dan Kepemimpinan Guru di Indonesia. Jakarta: Bumi Aksara.

Depdiknas. (2000). Pengelolaan Sekolah di Sekolah Dasar. Direktorat Pendidikan Dasar. Ditdikdasmen Depdikbud.

Fitri, E. (2020). Administrasi Keuangan Sekolah.

Janna, N. M., \& Arsyam, M. (2021). administrasi Keuangan dalam Pendidikan.

Nurhizrah, Gustituati. (2013). Manajemen Sekolah: Manajemen Program Non Akademik dan Hubungan Sekolah dan Masyarakat. Padang: UNP Press.

Rahmah, N. (2016). Prinsip-Prinsip Manajemen Keuangan Sekolah. Kelola: Journal of Islamic Education Management, 1(1), 73-77.

Sarbaini, S., ABBAS, E. W., Wahyu, W., \& SOFYAN, A. (2020). PENDIDIKAN KARAKTER.

Wijaya, D. (2013). Implikasi Manajemen Keuangan Sekolah Terhadap Kualitas Pendidikan. 